\title{
Influence of Discovery Learning-Based Empirical- Theoretical Study Assisted by Animation Phet on the Physics Problem-Solving in High School
}

\author{
Wartono Wartono, John Rafafy Batlolona \\ Universitas Negeri Malang \\ Malang, Indonesia \\ wartonoum@yahoo.co.id
}

\author{
Sholikhan, Choirul Huda \\ Universitas Kanjuruhan Malang \\ Malang, Indonesia
}

\begin{abstract}
The purpose of this study is to find the influence of discovery learning-based on an empirical-theoretical study with assistance Phet animation of the physic problem-solving in high school. The methodology used was a quasi-experiment with the pretest-posttest control group design. The technique of the sample collection was cluster random sampling. The score of the earlyability of treatment and control groups was obtained from the average of middle test score and final test score before the research was commenced. The results of the early ability of treatment and control groups weretested by using t-test to know that two groups were started based on the same academic levels. The data of the learners' physics problem-solving of two groups were obtained by the test ofWork and Energy after undergoing treatment. The data instrument of physics problemsolvingconsisted of 15 items. The hypothesis using ANAVA AB test. The results showed that learning inquiry-discovery based empirical-theoretical study with assistance Phet animation gives better influence on the physics problem-solving than the control group.
\end{abstract}

Keywords - Learning inquiry-discovery, Empirical-theoretical study, Animated Phet, Understanding the physics

\section{INTRODUCTION}

Education is significant in preparing the human resources to be reliable because education is believed to be be able to maximize potential of the students as a candidate of human resources that are reliable to be critical, logical and innovative in the face of and resolving any problems [1]. Learning is a process of work done by someone to obtain a new behavior change as a whole, as a result of his/her own experience of the interaction with the environment [2]. Thus, a person is said to be studying in the event of a change in the behavior thoroughly either in terms of understanding, drafting, habits, perceptions, interests, and the other skills.

In line with the development of the globalization era, science holds a very important role, because the quality of education usually is measured by the quality of the science community. Piasta [3] stated that the development of science and technology will be predicated on Mathematics and natural science. Science is very close to our daily life, the life of our surrounding and natural events that occur.
Physics is the science of phenomena relating to occurrences in day-to-day activities. However, in a world of education lesson, physics is often considered as a subject which is very difficult and thus the students do not like the physics subject. Physics subjects are much feared by students because there are many the ordinal and the equations of various reasons. In learning physics, the students must have curiosity, to be able to work openly, work hard and smartly, give their opinions and respect the others' opinions, adopt a resolution that can be responsible for, care for living things and the environment.

A lot of factors affect the success of learning activities, among others: the factors that come from the inside of students and come from outside of the students including a teaching method that is lacking effective, namely the students are regarded as a passive recipient. So, the attainment of the students' physics problem-solving is less than maximum.

Here are the evidence of the students' learning achievements that are low compared to the other subjects. To reach the purpose of physics learning the learning should be centered on the students and demand the students to be more active in learning.

Learning that can be conducted in physics learning is discovery learning, described by veterans [4] namely orientation, drawing up a hypothesis, testing the hypothesis, making inferences and evaluation [5]. Abdisa and Getinet [6] have suggested that a discovery is a method of teaching arranged in such a way so that the student acquire the knowledge that has not been had previously bynoticing, where some or all of the knowledge are found by the help of teachers.

By discovery learning, the students will experiment, take the data, analyze, conclude and communicate. Thus, they will directly involve in learning either physically and mentally. It will guarantee that the students will well understand the material studied in the empirical experience which is usually conducted in groups. In this group, peer tutoring is one of the benefits that may occur. The students who are lack of understanding will be explained by a friend who cleverer than them.

The knowledge gained by a student through the empirical experience and it is undertaken in this group, looks very easy, 
because it is assisted with the links and necessary assistance from the teacher. The student's knowledge obtained in the empirical experience will be longer and better if it is furnished with a theoretical review. This case could be done first by teachers then next submitted to each group. The students' knowledge, skills, and attitude are perceived through the empirical experience and theoretical review that enable the students to be a scientist in the field of physics.

Learning achievement according [7] is the result that has been achieved (carried, done and the like). Tella [8] defined achievement as a study result achieved by students based on certain criteria so as to know the level of learning achievements we need to a learning evaluation learning. By this discovery learning, the students are expected to perform the discovery in the empirical experience and to prove in theoretical review. Critical thinking in the last few years has been a term which is very popular in the education sector. For lots of reasons, the education becomes interested to teach skills to think his various shades. Critical thinking allows the students to uncover the truth from the information of the flood and the events around them every day. Systematic critical thinking is a process that enables the students to formulate and evaluate their own beliefs and opinions [9]. Physics problem- solving are put into research because they are considered capable of being an indicator of learning through discovery-based empirical and theoretical study that is successfully and optimized to be enforced.

\section{METHOD OF RESEARCH}

This study was conducted using a research design of quasi experiment or specious experiment. The research used pre-test design and post-test control group design. The test was given to the two groups before and after treatment/learning. The population in research was class xi IPA (natural science) of SMA 9, while the samples in this research were determined using clusters random sampling consisting of 2 classes of experiment and control with the total number of 70 students. Experiment class had 35 students and control class had 35 students.

An instrument measuring the capacity of problem-solving consists of 15 gratings of the discussion. The developed instrument refers to 4 indicators, namely: (1) understanding the problem, (2) making a plan, (3) following the plan assessing each step of your work, (4) and assessing the solution [10].

Polya's first step is critical to solve. Kola [11] found that when students are trained to identify and understand the concepts behind the problems, the gap between good problem solvers and weak problem solvers diminishes. Qualitative description of the problems can help the students to understand the problem.

Dhillon [12] described qualitative analysis as an essential activity in the problem-solving. Three students were taught to describe the problems with a diagram and to assess the diagram for consistency, they should have utilize the problem- solving [13]. Multiple representations of problems are helpful for the problem solvers [14]. Once the problem is understood, it is essential that students assess their work. They should make sure that each step makes sense and the answer makes sense as well. Providing explicit instruction on how to diagnose the errors of the problems improves the student's assessment abilities.

These indicators described in grating become the instrument of the tests of problem-solving ability. Next, the total score of the students was converted into value. However, prior to the test, the content validation and construction were performed by lecturers of physics education and theory of physics was tried out. After try out, the analysis of the grains was done to cover the level of hardship, test distinguishing power, test validity and the reliability. The results in validation and reliability were 0,71 and 0.29 .

The research data were analyzed by ANACOVA test to uncover the difference in the capacity of the problem-solving of the experiment and control groups. The data analysis was assisted by a program of SPSS version 16 for the window. Before analyzing the data, a prerequisite was executed namely normality and homogeneity test.

\section{RESEARCH RESULTS}

\section{A. Value of Problem Solving Ability}

A description of the value of problem-solving ability and the number of the samples selected in each category of the two groups of students was studied by analyzing the difference shown in Table1 based on the upper group in Table 2 and based on the bottom group in Table 3 .

\section{B. Normality Test}

Normality test in this research was conducted using the statistics of Kolmonogov-Smirnov and Shapiro-Wilk with the first significance of $5 \%$ assisted by the program of SPSS 16.0 for windows. The results of normality test of the level of physics problem-solving ability are presented in Table 4 .

TABLE I. VALUe of Problem-Solving ABILITy

\begin{tabular}{|l|l|l|l|l|l|}
\hline Groups & Learning & \multirow{2}{*}{$\begin{array}{c}\text { Number of } \\
\text { Samples }\end{array}$} & \multicolumn{2}{|c|}{$\begin{array}{c}\text { Value of Problem- } \\
\text { Solving Ability }\end{array}$} & \multirow{2}{*}{ Average } \\
\cline { 4 - 5 } & & & Highest & Lowest & \\
\hline Experiment & DLBET & 35 & 95 & 75 & 86,94 \\
\hline Control & CL & 35 & 77 & 54 & 66,45 \\
\hline & & & & & \\
\hline
\end{tabular}

TABLE II. VALUE OFProblem- SOLVING ABILITY OF UPPER GrouP

\begin{tabular}{|c|c|c|c|c|c|}
\hline \multirow[t]{2}{*}{ Group } & \multirow[t]{2}{*}{ Learning } & \multirow[t]{2}{*}{$\begin{array}{l}\text { Number of } \\
\text { Samples }\end{array}$} & \multicolumn{2}{|c|}{$\begin{array}{c}\text { Value of Problem } \\
\text { Solving Ability }\end{array}$} & \multirow[t]{2}{*}{ Average } \\
\hline & & & Upper & Lower & \\
\hline Experiment & DLBET & 10 & 95 & 75 & 76,34 \\
\hline Control & CL & 10 & 75 & 70 & 64,65 \\
\hline
\end{tabular}

TABLE III. VALUe OF Problem-Solving AbILITY of LOWER GRouP

\begin{tabular}{|c|c|c|c|c|c|}
\hline \multirow[t]{2}{*}{ Group } & \multirow[t]{2}{*}{ Learning } & \multirow{2}{*}{$\begin{array}{c}\text { Number } \\
\text { of } \\
\text { Samples }\end{array}$} & \multicolumn{2}{|c|}{$\begin{array}{l}\text { Value of Problem- } \\
\text { Solving Ability }\end{array}$} & \multirow[t]{2}{*}{ Average } \\
\hline & & & Upper & Lower & \\
\hline Experiment & DLBET & 10 & 74 & 55 & 72,94 \\
\hline Control & $\mathrm{CL}$ & 10 & 60 & 50 & 65,45 \\
\hline
\end{tabular}




\section{Homogeneity Test}

Homogeneity test in this research was performed by employing Levene' s test of equality of error variances to test homogeneity variance, with the standard of the 5\% significance helped by SPSS 16.0 for windows. The result of the test of homogeneity variance-covariance of physics problem-solving ability are presented in Table 5.

In Table 5 test results of homogeneity variance from the data, the ability problem-solving show significance (sig.) $\mathrm{w}$ greater than 0.05 .Thus can be concluded that data the ability problem solving, come from the homogeneous. The process calculation/data analysis to continue.

\section{Hypothesis Test}

The hypothesis test was conducted using Anacova (Analysis of Covariance) with the economic situation of 5\% assisted by the program of SPSS 16.0 for windows. The consecutive Anacova analysis resulted in the multivariate tests to investigate the differences presented in Table 6 and the difference of the dependent variables test between-subjects effects are presented in Table 6.

The results of ANCOVA tests presented in Table 4 and Table 5 show the test result procedures of Pillai's Trace, Wilks' Lambda, Hotelling's Trace, and Roys's Largest Root on the effect of learning all indicate the significance (sig.) $=0.000$ $<0.05$ and the results displayed in table 4.6 show the dependent variables against learning source of critical thinking level gleaned $F=18,354$ with the significance $($ sig. $)=0.000<0.05$. Thus, Ho was rejected and H1 was accepted; this case means that the problem-solving learned by discovery learning through the empirical and theoretical review, was higher than by learning conventional seen from the average of the problemsolving ability of the students who learned using discovery learning through an empirical and theoretical review which was 86,94, while the students who learned using learning conventional gained the mean of 66,45 .

TABLE IV. The Results of NoRmality Test of Problem-Solving ABILITY

\begin{tabular}{|c|c|c|c|c|c|c|}
\hline \multirow[t]{2}{*}{ Learning } & \multicolumn{3}{|c|}{ Kolmogorov-Smirnova } & \multicolumn{3}{|c|}{ Shapiro-Wilk } \\
\hline & Statistic & $d f$ & Sig. & Statistic & $d f$ & Sig. \\
\hline DLBET & .141 & 34 & .087 & .948 & 34 & .107 \\
\hline $\mathrm{CL}$ & .141 & 34 & .095 & .895 & 34 & .004 \\
\hline
\end{tabular}

TABLE V.

TEST OF HOMOGENEITY VARIANCE OF PROBLEMSOLVING ABILITY

\begin{tabular}{|c|c|c|c|c|c|c|}
\hline \multicolumn{7}{|c|}{ ANACOVA Tests } \\
\hline \multicolumn{2}{|c|}{ Effect } & \multirow{2}{*}{$\begin{array}{l}\text { Value } \\
.995\end{array}$} & \multirow{2}{*}{$\begin{array}{c}\mathbf{F} \\
6.016 \mathrm{E} 3 \mathrm{a}\end{array}$} & \multirow{2}{*}{$\begin{array}{c}\begin{array}{c}\text { Hypothesis } \\
\text { df }\end{array} \\
2.000\end{array}$} & \multirow{2}{*}{$\begin{array}{c}\begin{array}{c}\text { Error } \\
\text { df }\end{array} \\
64.00\end{array}$} & \multirow{2}{*}{$\begin{array}{l}\text { Sig. } \\
.000\end{array}$} \\
\hline Intercept & $\begin{array}{l}\text { Pillai's } \\
\text { Trace }\end{array}$ & & & & & \\
\hline & $\begin{array}{l}\text { Wilks' } \\
\text { Lambda }\end{array}$ & .005 & $6.016 \mathrm{E} 3 \mathrm{a}$ & 2.000 & 64.00 & .000 \\
\hline & $\begin{array}{l}\text { Hotelling's } \\
\text { Trace }\end{array}$ & 187.995 & $6.016 \mathrm{E} 3 \mathrm{a}$ & 2.000 & 64.00 & .000 \\
\hline & $\begin{array}{l}\text { Roy's } \\
\text { Largest } \\
\text { Root }\end{array}$ & 187.995 & $6.016 \mathrm{E} 3 \mathrm{a}$ & 2.000 & 64.00 & .000 \\
\hline \multirow[t]{4}{*}{ Learning } & $\begin{array}{l}\text { Pillai's } \\
\text { Trace }\end{array}$ & .243 & $10.275 \mathrm{a}$ & 2.000 & 64.00 & .000 \\
\hline & $\begin{array}{l}\text { Wilks' } \\
\text { Lambda }\end{array}$ & .757 & $10.275 \mathrm{a}$ & 2.000 & 64.00 & .000 \\
\hline & $\begin{array}{l}\text { Hotelling's } \\
\text { Trace }\end{array}$ & .321 & $10.275 \mathrm{a}$ & 2.000 & 64.000 & .000 \\
\hline & $\begin{array}{l}\text { Roy's } \\
\text { Largest } \\
\text { Root }\end{array}$ & .321 & $10.275 \mathrm{a}$ & 2.000 & 64.000 & .000 \\
\hline \multicolumn{7}{|c|}{ a. Exact statistic } \\
\hline \multicolumn{7}{|c|}{ b. Design: Intercept + Learning } \\
\hline \multicolumn{7}{|c|}{ Levene's Test of Equality of Error Variances } \\
\hline & $\mathrm{F}$ & \multicolumn{2}{|l|}{ df1 } & df2 & \multicolumn{2}{|l|}{ Sig. } \\
\hline $\begin{array}{l}\text { Problem } \\
\text { Solving } \\
\text { Ability }\end{array}$ & .096 & \multicolumn{2}{|l|}{1} & 68 & \multicolumn{2}{|l|}{.757} \\
\hline \multicolumn{7}{|c|}{$\begin{array}{l}\text { Tests the null hypothesis that the error variance of the dependent variable is } \\
\text { equal across groups. }\end{array}$} \\
\hline
\end{tabular}

TABLE VI. THE RESULTS OF THE ANCOVA IN TERM OF THE DIFFERENCE OF EACH DEPENDENT VARIABLE

\begin{tabular}{|l|l|l|l|l|l|l|}
\hline Tests of Between-Subjects Effects & $\begin{array}{l}\text { Mean } \\
\text { Source }\end{array}$ & $\begin{array}{l}\text { Dependent } \\
\text { Variable }\end{array}$ & $\begin{array}{l}\text { Type III } \\
\text { Sum of } \\
\text { Squares }\end{array}$ & Df & $\begin{array}{l}\text { Mean } \\
\text { Square }\end{array}$ & \\
\hline $\begin{array}{l}\text { Corrected } \\
\text { Model }\end{array}$ & $\begin{array}{l}\text { Problem- } \\
\text { Solving } \\
\text { Ability }\end{array}$ & $938.622^{\mathrm{a}}$ & 1 & 938.622 & 18.354 & .000 \\
\hline Intercept & $\begin{array}{l}\text { Problem- } \\
\text { Solving } \\
\text { Ability }\end{array}$ & 320747.578 & 1 & 320747.578 & $6.272 \mathrm{E} 3$ & .000 \\
\hline Learning & $\begin{array}{l}\text { Problem- } \\
\text { Solving } \\
\text { Ability }\end{array}$ & 938.622 & 1 & 938.622 & 18.354 & .000 \\
\hline Error & $\begin{array}{l}\text { Problem- } \\
\text { Solving } \\
\text { Ability }\end{array}$ & 3324.064 & 65 & 51.139 & & \\
\hline Total & $\begin{array}{l}\text { Problem- } \\
\text { Solving } \\
\text { Ability }\end{array}$ & 325600.000 & 67 & & & \\
\hline $\begin{array}{l}\text { Corrected } \\
\text { Total }\end{array}$ & $\begin{array}{l}\text { Problem- } \\
\text { Solving } \\
\text { Ability }\end{array}$ & 4262.687 & 66 & & & \\
\hline
\end{tabular}

c. $\mathrm{R}$ Squared $=.220($ Adjusted R Squared $=.208)$

d. b. R Squared $=.059($ Adjusted R Squared $=.044)$ 


\section{DISCUSSION}

The research results indicated that the mean of problemsolving ability of the students who learned using discovery learning was higher than that of the students learned through conventional learning. The students who studied through discovery learning participated more actively in learning served because they were given the chance to find their own knowledge that want to be transmitted by direct trial. Based on Wilcox's opinion [15], the students' experiences, using discovery learning model, are driven to learn mostly through the active involvement of their own by concepts and principles, and teachers get students to have experience and experiment which allow them discover the principles for themselves [16].

In accordance with the research conducted by [17], a teacher must attempt to use the approach of social interaction discovery or guide discovery to engage the students in problem-solving activities, self-learning, critical thinking and understanding, and creative learning. The important thing is in discovery learning, the students are given the opportunity to conduct experiments, develop their curiosity when they perform an experiment, then they find their hypotheses and conduct discussions regarding the results of the experiments conducted.

By the benefits of discovery learning through empirical and theoretical review that have been explained, the results are better than using conventional lessons regarding the critical thinking. When Archimedes experiment was conducted in the experimental classes, the students were more active and enthusiastic in doing the experiments, a sense of students'. The students were very active and they felt happy because they could find their own sound of the Archimedes law through the experiment. According to [18], discovery learning guide provides opportunities for class activities based on the student (student-centered) and lets the students learn so that the teacher is not the only source of learning.

According to [19], the advantage of student learning model is to spur and learn independently in solving the problems. Therefore, in this study, the students who learned to solve the problems using discovery through the empirical and theoretical review got the higher score than that of the students who learned conventionally. As we know, the physics lesson, like science, demands the learner to understand through an experiment.

\section{CONCLUSION}

The problem-solving ability of the students who learned using discovery learning through the empirical and theoretical review was higher than that of the students who learned conventionally so discovery learning through the empirical and theoretical review is more effective in improving the problemsolving ability.

Based on the research results and discussion of the implementation of the research then researcher mentions several advices as follows: (1).This research was conducted in a public high school in urban areas; it is recommended to the other researchers to implement it in the high school in the mountainous regions. (2) The learning topic in this research was only regarding the static fluid so the research results were limited to the material. Therefore, it is suggested for the similar research to be conducted on the different characteristics to know whether the discovery learning through the empirical and theoretical review. (3) In this research, the discovery learning through the empirical and theoretical review was directly executed on the application in the experiment group experiment without conditioning the group first. This case leads the students have to adapt to this learning model. It is recommended to the others, to firstly customize so that the students do not face difficulty in this learning model.

\section{REFERENCES}

[1] I. J. Quitadamo and M. J. Kurtz, "Learning to improve: using writing to increase critical thinking performance in general education biology," CBE-Life Sci. Educ., vol. 6, no. 2, pp. 140-154, 2007.

[2] M. J. Fryling, C. Johnston, and L. J. Hayes, "Understanding observational learning: An interbehavioral approach," Anal. Verbal Behav., vol. 27, no. 1, pp. 191-203, 2011.

[3] S. B. Piasta, C. Y. Pelatti, and H. L. Miller, "Mathematics and science learning opportunities in preschool classrooms.," Early Educ. Dev., vol. 25 , no. 4, pp. 445-468, 2014.

[4] W. Van Joolingen, "Cognitive tools for discovery learning," Int. J. Artif. Intell. Educ., no. 10, pp. 385-397, 1998.

[5] C. Howe, A. Tolmie, A. Anderson, and M. Mackenzie, "Conceptual knowledge in physics: The role of group interaction in computersupported teaching," Learn. Instr., vol. 2, no. 3, pp. 161-183, 1992.

[6] A. Abdisa and T. Getinet, "The effect of guided discovery on students' Physics achievement," J. Phys. Educ., vol. 6, no. 4, pp. 530-537, 2012.

[7] G. Abdisa and T. Getinet, "The effect of guided discovery on students' Physics achievement," J. Phys. Educ., vol. 4, no. 6, pp. 530-537, 2012.

[8] A. Tella, "The Impact of Motivation on Student's Academic Achievement and Learning Outcomes in Mathematics among Secondary School Students in Nigeria," Eurasia J. Math. Sci. Technol. Educ., vol. 3, no. 2, pp. 149-156, 2007.

[9] L. G. Snyder and M. J. Snyder, "Teaching critical thinking and problem solving skills," J. Res. Bus. Educ., vol. 50, no. 2, pp. 90-99, 2008.

[10] polya george, "Polya's Problem Solving Techniques," 1957.

[11] A. J. Kola, "Investigating the Conceptual Understanding of Physics through an Interactive LectureEngagement," Cumhur. Int. J. Educ., vol. 6, no. 1, pp. 82-96, 2017.

[12] A. S. Dhillon, "Individual differences within problem-solving strategies used in physics," Sci. Educ., vol. 82, no. 3, pp. 379-405, 1998.

[13] F. Reif and J. I. Heller, "Knowledge structure and problem solving in physics," Educ. Psychol., vol. 17, no. 2, pp. 102-127, 1982.

[14] D. Rosengrant, E. Etkina, and A. Van Heuvelen, "An overview of recent research on multiple representations," AIP Conf. Proc., vol. 883, no. 1, pp. 149-152, 2007.

[15] R. E. Slavin, "Cooperative learning, success for all, and evidencebased reform in education," Éducation Didact., vol. 2, no. 2, pp. 149 157,2008

[16] A. G. Balım, "The Effects of Discovery Learning on Students' Success and Inquiry Learning Skills," Eurasian J. Educ. Res., no. 35, pp. 1-20, 2009.

[17] N. Makoolati, M. Amini, H. Raisi, S. Yazdani, and A. V. Razeghi, "The Effectiveness Of Guided Discovery Learning on The Learning and Satisfaction of Nursing Students," Hormozgan Med. J., vol. 18, no. 6, pp. 490-496, 2015.

[18] L. Alfieri, P. J. Brooks, N. J. Aldrich, and H. R. Tenenbaum, "Does Discovery-Based Instruction Enhance Learning?," J. Educ. Psychol., vol. 103, no. 1, pp. 1-18, 2011.

[19] W. Wartono, M. N. Hudha, and J. R. Batlolona, "How Are The Physics Critical Thinking Skills of The Students Taught by Using Inquiry- 
